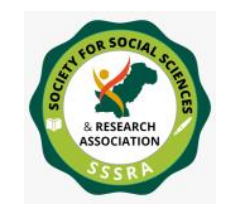

Pak. Journal of Int'L Affairs, Vol 4, Issue 4 (2021) Allama Dr Muhammad lqbal's Philosophy of ...

\title{
ALLAMA DR MUHAMMAD IQBAL'S PHILOSOPHY OF ISLAMIC CULTURE AND MORAL VALUES AND CONTEMPORARY MUSLIM WORLD: AN ANALYTICAL AND CRITICAL STUDY
}

\author{
Muhammad Umar Riaz Abbasi \\ PhD Scholar \\ National University of Modern Languages \\ Islamabad-Pakistan \\ drumarabbasi101@gmail.com \\ ORCID: http://orcid.org/0000-0001-6977-9516
}

\begin{abstract}
Historically, religion along with the culture and civilization have always advanced in accordance with one another. Undoubtedly, development of culture without that of religion is not possible. Therefore, this amalgamation and inter-dependence of religion as well as culture is the fundamental crux of Muslim cultural and moral view of Dr. Allama Muhammad Iqbal. For Muhammad Iqbal, most significant element in the life of Muslims is its culture and moral values. For the development of Muslim society among the entire globe, Iqbal focused mainly on culture and morality, instead of political and economic influence of the state. Though, Iqbal had a deep insight about the western view, still he formulated his though in accordance with the guidance provided by Quran and Hazrat Muhammad Mustafa SAWW. As, in the modern-day world, morality of the individuals is based entirely upon their own choices and orthodox preconceptions. Furthermore, morality is dependent upon the culture also it seems to be conservative in the context of modern era. The followers of traditions are at conflict with the followers of modernization and considers them to be fundamentalists. However, the traditionalists are aware of this fact that their system of value is resilient against any sudden change. However, the trends and fashions of the modern age thought not completely inaccurate transmits within the generations. This review paper thus mainly focuses on exploring the philosophy of Dr. Allama Muhammad Iqbal about the culture of Muslims along with their morality. Also, it would cornerstone the contemporary situations of the Muslim world under the influence of Iqbal's philosophy. Though it does not determine the constitutional factors of cultures and traits of Muslim society however, it is




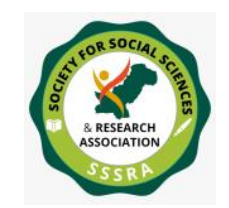

Pak. Journal of Int'L Affairs, Vol 4, Issue 4 (2021) Allama Dr Muhammad lqbal's Philosophy of ...

an attempt to exhibit the critical appraisal of Dr. Iqbal about the nature of culture of Muslims as well as the fundamental ideologies which are motivating, inspiring, and directing the Muslim societies in their pursuit of moral values and culture.

Key words: Philosophy, Iqbal, Muslim culture, Moral values, Reconstruction of religious thoughts, Contemporary Muslim world

\section{Introduction}

The focal discussion of this review article is regarding the personality of Dr. Allama Muhammad Iqbal together with his philosophy about the culture of Muslims and their morality. Furthermore, the growing trends of the contemporary Muslim world are also analyzed in terms of comparison with the view of Iqbal. Allama Iqbal (1877-1938) was a reverent Muslim, significant philosopher, proficient poet, as well as impelled activist. Different people were connected to him differently. Some people were attached to him because of progressiveness, religious modernism, and devotion towards Islam, whereas to some people he was an iconic westernizer. The nation of Pakistan, however, considers Allama Iqbal as a father of their homeland i.e., Pakistan. In the context of academia, Allama Iqbal is an enchanting paradigm who reconciled the ideas of Muslims with contemporaneousness. Allama Iqbal is kindred to Imam Ghazali of the $20^{\text {th }}$ century, one who synthesized modernity, mysticism, and Islam. Additionally, Iqbal encouraged the notion about the stated based upon religion without stimulating cliched and obnoxious representation of vicious theocracy (Iqbal, 2015).

The Reconstruction of religious thought in Islam is the masterpiece scripted by Dr. Allama Muhammad Iqbal. In this scripture he has discussed just a little bit about Islam, may be due to the fact that this manuscript was initially introduced just as a lecture. Whereas, in his poetic scripture- Ramooz-e-Bekhudi i.e., The secrecies of altruism, Dr. Iqbal has written a complete section with the title of "Pillars of Islam'. Rather than describing Islam, he has analyzed Tawheed, "the entirety and solidarity of Allah", together with the notion of Prophecy in the religion of Islam. Both of these conceptions are significantly important factors of the integrated and global Islam that Allama Iqbal pursues. Tawheed is considered to be the fundamental fountainhead of conviction that attenuates the trepidation together with every pessimistic sentiment that restricts the Muslims. Moreover, in his scripture, "The reconstruction of religious thought in Islam", Iqbal delineates Tawheed as solidarity, freedom, and equality". According to the believes of Iqbal, believing in the uniqueness of Allah is something that results in believing in individualism. Also, it is the reflection of solidarity of Allah i.e., Tawheed in the believer. 


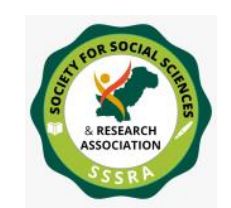

Pak. Journal of Int'L Affairs, Vol 4, Issue 4 (2021) Allama Dr Muhammad lqbal's Philosophy of ...

Furthermore, Iqbal implicates this notion in every human of the community in another masterpiece, Baang-e daraa. The vision of Allama Iqbal about Islam is focused on unifying every believing Muslim living individually or communally. Paradoxically, might be the Islam of Iqbal is not just intellectual, but potential religion which is stimulated by the objectives inclusive of self-empowerment, community-empowerment, and liberties of the politics. To make his point of view clear, Iqbal keeps intellectualism separated from vitalism by tagging intellectualism as just the comprehension of connection. On the other hand, vitalism is considered to be the enhanced acceptance which is quite equal to ImaanBelief in terms of meanings. On contrary to the belief based upon intellectualism, Imaan is reflected through the action of the believers. Allama Iqbal ascribes the orientation of Islamic actions to those of Prophet Muhammad Mustafa SAWW and attributed Him to be the very first spirituality positivist, pragmatist, as well as psychologist. In endorsement of his thoughts, Iqbal referred to the various sayings together with the deeds of Holy Prophet PBUH i.e., Hadiths of Prophet PBUH. Iqbal emphasizes the virtues of Prophet PBUH as the testimony for his personality as Insaan-e-Kaamil, specifically underpinning creative potential of the spirit of Prophet PBUH. Finally, Iqbal pondered upon acknowledging several perspectives of Islam. Though Iqbal is the supporter of his Islam and considered it to be the one of its kind in true essence, still he demonstrated the consciousness of all other perspectives and aspects of Islam. In his other scripture, Zarb-e-Kaleem, Iqbal mentioned about thinking about new Islam. This recognition of multiple Islams highlights two significant factors related to the philosophy of religion of Iqbal. The first important factor is the recognition of Iqbal about his target audience as well as his awareness about the distinction amidst scriptural and practical Islam.

The second significant factor is his acknowledgement about the empowerment of Islam on individual level to conquer established form of Islam (Iqbal, 2013). In accordance with the writings of Allama Iqbal, moral values are the obstinate codification of conduct allowing liberated self-esteem to attain their maximum prospective. Application of the determination of morality through denial, concept of Iqbal about morality can be comprehended by having an insight of what morality might not be. Neither, morality is pragmatic, nor it is defined already. Factually, morality is a definite approach of behavioral aspects having right, wrong as well as good and bad features. Allama Iqbal opted this definition of morality based upon the behavioral aspects due to the fact that morality operates as the codification of conducts for liberated self-esteem, that permits them to attain their maximum capabilities (Al-Azhari, \& Ghuman, 2019). Allama Iqbal is a categorical representative of moral autocracy. Also, he has strengthened this argument by explaining the concept of Ijtehaad in the reconstruction of religious thoughts in Islam, where Ijtehaad is the legitimate action for the derivation of moral constitutions. There he stated that the only option we are left with is to remove the hard sheath from Islam that has 


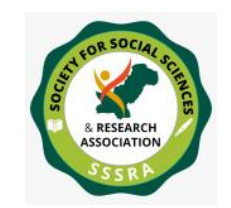

Pak. Journal of Int'L Affairs, Vol 4, Issue 4 (2021) Allama Dr Muhammad lqbal's Philosophy of ...

made stationary the important dynamic perspectives about man's life, also to find again the innovative assortments of equality, solidarity, and freedom with the aim of reconstructing our political, social, as well as moral approaches from their fundamental resources of simplicity together with universality. Furthermore, the belief of Dr. Iqbal on the precept of Tawheed is a crux of his moral certainties (Ashraf, 2003). Morality never changes, merely the comprehensions of legislations reporting morality alters.

These altering comprehensions of the ways of developing high morals are applicable on every single being regardless of the creed they belong to or the religion they follow. The inquisition then arises about the source of moral values of Allama Iqbal, which can be replied by the detailed examination of his affirmations, such as equalizing Shariahthe divine legislation and moral values. Also, Fiqh-the legislations interpreted by the man, should modify based on the alteration in Shariah. Therefore, whatever is legitimate according to Shariah and Fiqh, would be considered moral. The fountainheads of moral values are thought to be the origins of law or Usool-al-Fiqh; The Holy Quran, The Prophetic sayings-Ahadith, Consensus of the religious scholars-Ijmaa, the Qeyaasinferential philosophy, and Ijtehaad for the modification of frame of references. The initial two fountainheads are generally recognized as the origins of Shariah, however, the following two are established as the root of Fiqh (Khan, Akbar, Jam, \& Saeed, 2016). Though Allama Iqbal did not exemplify the moral values, yet he vociferously determined the absolute actions-based morality. Allama Iqbal rationalized moral values that are articulated to the absolute standards of Shariah which are comprehended by the man in a better way with the passage of time. That is why, the actions which were considered to be virtuous in the $16^{\text {th }}$ century might not remain so in the $20^{\text {th }}$ century as achievement of the same righteousness has advanced. The comprehensive philosophy of Allama Iqbal is based upon the holistic insight of the circumstances inclusive of good or bad incidents. There exists nothing like the isolated fact as facts are something based on the methodical discretions, whose factors should be comprehended by mutual consent. There exist absolute principles about what is good and what is evil, therefore a man should continuously try hard to achieve the good moral attributes to achieve the self-esteem as per standardized by the principles, however, categorical division of good and bad acts is not possible as they share symbiotic connection (Tatlah, 2011).

Intention behind performing any action is also a standard explained by Allama Iqbal, as according to him, intention is a core belief of Islam and is something which is judged by Allah for the determination of the moral or immoral base of any action a man performs. Intention is considered to be the aesthetic mental feeling of doing an action which ultimately defines its nature. So collectively, the current circumstantial apprehension of Shariah, influence of the personal choices on surrounding people, and most importantly 


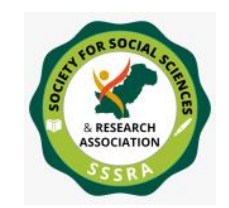

Pak. Journal of Int'L Affairs, Vol 4, Issue 4 (2021) Allama Dr Muhammad lqbal's Philosophy of ...

intention behind any act is the crux of deciding about the actions, whether they are moral or immoral. Any action performed without thinking about its impact on afterlife would be considered immoral as well as profane. Nevertheless, no man is the judge of anyone's action, but the one and only, Almighty Allah, the Divine power. As Iqbal stated, "Allah knows the best, what you all do, He is the only one to judge your actions on the judgement day" (Muzaffar, 2002). Conclusively, intersection of Islam and moral values is simple which demonstrates that being moral in the true sense reflects the indulgence of self in moral attributes with the help of opting moral routes. This pursuance of morality with the aim of achieving freedom is the objective defined by Islam. Therefore, moral values and Islamic culture are one end the same thing. The significance of Islamic philosophy of Iqbal along with its all shades are the fundamental focal points of this study. His courageous debates about Islam would remain substantial in the arena of academics as well as in the thoughts of Muslims from Southern-Asia. Although Pakistan has not yet been evolved in accordance with Iqbal's dreams, yet still Allama Iqbal is the demonstration of what some commentators of contemporary era argue they want from Muslim world. Delving in the philosophy of Iqbal about religious culture and morality, his originative contribution towards Islam and Muslim, the reconstruction of religious thought in Islam along with his other poetic scriptures would be employed as a main reference in this article (Puspitasari, 2019).

\section{Research Objective and Methodology}

Aim of this study is the establishment of comprehensive discussion regarding the philosophy of Iqbal about the culture and moral values of Muslims. Furthermore, in this study, the contemporary Muslim world in accordance with Iqbal's philosophy have been analyzed. Finally, followed by the critical analysis of aforementioned subject, recommendations have been devised under the light of the teachings of Iqbal for the betterment of the modern Muslim world.

Research methodology being opted for the current study is analytical and critical.

\section{WHO IS IQBAL?}

Allama Iqbal was God gifted by sky scraping revolutionary perception and analysis. In the early twentieth century, Dr. Muhammad Allama Iqbal was well-known Muslim poet, a great scholar and lawmaker of sub-continent. He was born on $9^{\text {th }}$ November 1877 in the city of Sialkot, Punjab, Pakistan. He belonged to a family of Kashmiri, brahmans who had accepted Islam in the seventeenth century. Allama Iqbal completed his Bachelor and master's degree in Philosophy from government college university Lahore. For higher 


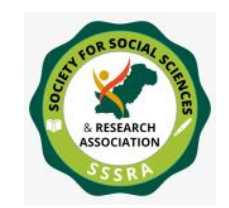

Pak. Journal of Int'L Affairs, Vol 4, Issue 4 (2021) Allama Dr Muhammad lqbal's Philosophy of ...

education, He moved to England where he studied law and neo-Hegelian philosophy in Cambridge university. In 1907, At the university of Munich, Heidelberg, he learnt German language, got doctorate degree, and submitted a thesis on "The Development of Metaphysics in Persia". After returning to Pakistan, while performing law, Iqbal taught philosophy and English literature in government college university Lahore. Allama Iqbal was well-informed in Islamic philosophy and had broadly studied Al-Ghazali and ibnArabi. Iqbal, a thinker, gave the vision of separate homeland for Indian's Muslims. He wanted the separate state for Muslims where they can live as per the principles of Quran and their own culture and habits which were not possible in subcontinent. The Vision of separate country for Indian's Muslims made him devotional father of Pakistani state (Britannica, T. Editors of Encyclopaedia, 2020, May 2).

\section{The Reconstruction of Religious Thoughts in Islam}

Iqbal commended the revival of Islam through the love of God and active development of the self. The reconstruction of religion in Islam is the compilation of series of lectures of Iqbal which were given at the Aligarh university and Muslim associates of madras Hyderabad From December 1928 to January 1929. In 1930, six lectures were compiled which were later published in English language by Oxford university press in 1934 with an extra book chapter named "is religious possible"? This work shows the clearest declaration of Iqbal's religious point of view and concerns about Islam in Indian subcontinent. In his all lectures, he discussed about theory of knowledge, concepts of God and Religion, religious experiences, Khudi (the self), the spirit of Muslim heritage and the inherent strength within Islam. A leading attribute of his work is repeated references which are both accepting and critical, to European thinkers. The most notable indications are Alfred whitehead, Nietzsche, and Henri Bergson with brief references to Darwin and William James. In his work he also mentioned Quranic verses and other sub continental's poets as references. He wants to fortify his points among Muslims audience. The most important feature of this book is that it illustrates Iqbal's plan for keeping Islam's basic principles while adopting modernism. Iqbal expresses in his preface, "The Quran is a book which highlights 'deed' instead of 'idea. In the world of scientific discovery and modernism, this statement set the value of his entire dialogue of Islamic transformation (Iqbal, 2013).

In brief, the purpose of religion is the guidance and modification of man's outer and inner life. Despite these attractions to modification and action, Iqbal outlines Muslim world as knowledgeably dead and internally turning towards west. This mentally increases modernism and covetousness which obviously is not the indication of negativity, but Iqbal thought that it's the loss of Islamic cultural heritage as Muslims are attracting to west sensations and they were unable to recognized Islamic values and ethics. In the chapter of 


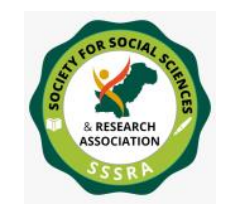

Pak. Journal of Int'L Affairs, Vol 4, Issue 4 (2021) Allama Dr Muhammad lqbal's Philosophy of ...

"is religion possible" Iqbal glorified the Islamic imaginative life and he challenged Muslims to perceive destiny (taqdeer) as: through one's effort internal capabilities can be attained. Iqbal described mature fatalism is that it is not the denying of ego, but it is the life which is full of power and sees no hurdles which allows a man to offer his prayers even if gunshots are spilling around him. He re-focuses on Quran significance that actions are better than intentions. The basic purpose of ego to be is to not to follow something but to be something. You cannot see the world through knowledge of concepts, but it is something to be made and remade through mindful actions. In his lectures, he wanted to urge Muslim ummah to alter himself or adjust with passage of time and change in information. His purpose was not to change Islam in the inventions of twentieth century but to inform others the values and standards of Islam with the use of new and modern knowledge and information (Ali, 2017). The Islamic values was kept the same, but Iqbal wanted to change the way or procedure to which individuals can understand the concept. Iqbal trusted that personal empowerment comes from religion which he mentioned both as rational and non-rationale. Iqbal thought that emotions and feelings of believers are much important than knowledge of religion as actions are driven by feelings and emotions.

He says that there should be balance between spirit and intellect. Western religiophilosiphical ideas managed to encourage that the idea of personal freedom is directly oppose to ethical restraints required by Islamic religion. Iqbal did not agree to this statement. According to him, religious maturity come through three stages of development and from these stages' religion become a personal matter of immersion of life and strength and one achieve a free individuality by finding the important source of law within the depth of his own awareness or consciousness. Empowerment come from the hidden understanding of oneself by attaining a deeper understanding of wisdom enclosed in religion (Khaja, 2018). As far as the nature of reality is alarmed, nothing is at pole in the progress of science but the whole race of ego is at pole in the religious progress or venture (Popp, 2019). The purpose of Islam is to discover oneself, one's goal or purpose, and building one's destiny. Allama Iqbal believed that in Islam, the best experience is religion liberating power. This believe was clear in his comparison of Islam to Buddhism, Hinduism, Judaism, and Christianity. He compared Christianity as a religion of spirituality to Judaism as a religion of legality. Iqbal knows more about Christianity as he was given his education background with Christian missionaries. He mentioned that Christians focused on spiritual not temporal. For describing Christianity's ideal social and political disinterest in worldly affairs Iqbal cited Fredrich Naumann (Briefe über Religion). Iqbal's thoughts on Hinduism were not positive as Hinduism is caste-based religion. Iqbal's views on Buddhism are mentioned in Islam as a political and moral ideal and he thought that Buddhism are pain leaders to other worldwide. Mentioned to these comparison Iqbal believed that Islam is a religion of self-empowerment as it does not bound people to adhere 


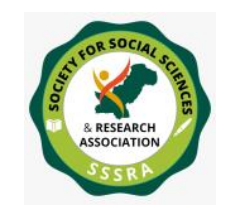

Pak. Journal of Int'L Affairs, Vol 4, Issue 4 (2021) Allama Dr Muhammad Iqbal's Philosophy of ...

on legality, Christianity, Buddhism or to encourage Hinduism. In Islamic religion, man is not slave, and a responsible being. He is free in making his own decisions, his destiny, his salvation in his own business. There is no one between God and man. Man, and God has direct relationship. Islam's freedom and agency is the most suitable religion for man's empowerment (Khan, Akbar, Jam, \& Saeed, 2016).

\section{Iqbal's philosophy of Muslim Culture}

The foremost core aspect of Muslim culture is the philosophy of Self, defended by Mohammad Allama Iqbal.

The proposed philosophy is among one of his great chores first written in the Persian language such as Asrar-e-khudi and Rumuz-i-khudi. Which later translated into other languages such as in the English language by Professor R.A. Nicholson from Cambridge University, entitled "The Secrets of the Self". It renders the philosophical concept of the Self, (personality of an individual). The Secrets of self, followed by another translation of Iqbal's chore: Rumuz-i-bekhudi by a Professor A.J. Arberry into the English language, entitled "The Mysteries of Selflessness" which means the individual towards society. Due to acquiring the paramount importance to Iqbal's work, the notion of his great philosophy, "The Self" was further comprehended systematically in his idyllic chores and in his lectures, more specifically, when it comes to "The Reconstruction of Religious Thoughts in Islam". Allama Iqbal enlightened the need for understanding the nature of the Self to understand the nature, (surrounding) of civilized culture and principles of its growth. Iqbal mentioned the relation of the Self with the dynamics of life. He further elaborates the Self, an energetic and divine creation of a being. Through which an individual shall contend to acquire the divine horizons of his personality and to get indulged in happenings of the universe to reach the pinnacle of an ambassador of God on earth. " Though the Self exhibits the central importance of one's (a person) manoeuvres". On which, Allama-Iqbal renunciate the other sets of philosophical and religious notions bolstering contradictions against the (Self) and its actuality (Ali, 2011).

These unrestrained philosophical concepts also proposed the existence of Self as a misperceived idea. Also renders apathy, idleness, and dormancy as the allured things at most which seem paradoxical to the universal reality and its endeavours of life in relation with austerity. Hence, Iqbal defied their dogma of Self-induced meanings of the (Self) which is not only ruthless but also contradicts the Islamic perspective of the (Self). He also briefed an example of Muslim's downfall due to the misguidance of those schools of thought. On the other hand, Iqbal proposed the ideal notions of having the right morals in compliance with a religious perspective are just Self Actualization and Self-affirmation. 


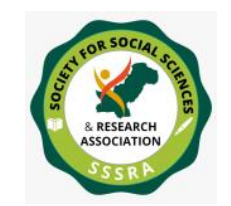

Pak. Journal of Int'L Affairs, Vol 4, Issue 4 (2021) Allama Dr Muhammad lqbal's Philosophy of ...

Though the creation of Mankind is the paramount creativity of God, an individual shall discern his being as the foremost strength, and the likelihood to groom his spiritual presence to make society better (Abbas, 2017). Iqbal mandates the irregular and optimum fluctuation in (Self) always perpetuates the hike and decline of nations. To achieve enlightenment, it is an imperative act to strengthen your (Self). Also, it is the Self, which empowers to stand against the grain and in strong adversities. Perhaps, any nation will embrace disparities if they abandon their (Self). According to this perspective, the Universal relation of (Self) to matter(surroundings) and with the Culture an individual drives through Self. Which bestows one purpose of being an ambassador of God in life to live on Earth. Moreover, Allama Iqbal phrased the spiritual perspective into a SelfDevelopment. And ingeniously correlates with another notion known as "the liberty"(freedom) (Amin, 2012). Which elaborates that real liberty or freedom is the freedom of self. Perhaps the current existence of self is not in the matured form, to get off free from all uncertainties, an individual ought to tune his (Self) according to the guiding principles of God to be responsible and accountable. Which is the mere message in the spirit of Islam that bestows the comprehensive code of life. Following God's guidance, an individual's self is free to do anything in the vicinity of purity and spirituality which makes the (Self), a divine power, and the submission of self towards God. Iqbal mentioned the ability to surrender the self and love towards God, the utmost right to progress and nourish the (Self), the initial stage of self-development.

He explicitly stated the pinnacle of Self-development by being an ambassador of God. And devoting the self to righteous activities under the guiding principles of God to make the society better and peaceful in the Spirit of Islam. In defending the Muslim culture, he intensified the unseen relation of an individual's self with material(matter) and spirituality. He voiced through his insightful philosophies that the Materialistic world and the spiritual aspect of being are not two annihilating forces. Rather, they are merely connected in such a pattern that it all combines into One, the Self of an individual (Saeed, 2013). Though the matter (materialistic world) and spirituality are indivisible. Connecting these two aspects increase the intellectual and bestows transformations in culture to be civilized. Indeed, He cited the two significant terms which act as mind provoking for example, Alam-i-anfus (Spiritual world), Alam-i-afaq (material world). He vigorously opposed the contradicting schools of thought against both the spiritual and material world. He declared the utmost truth putting both the spiritual and material world in one perspective. He renunciate the predominance of one world over another and cited rationalism to bolster the unity of both in his poetical works. On the other hand, he expanded his philosophy by proposing another constituent of Muslim Culture, which is a society. Iqbal defended the concept of society by emphasizing the true essence of the Self of an individual. He explained that the (self) is quite versatile which is broader than the 


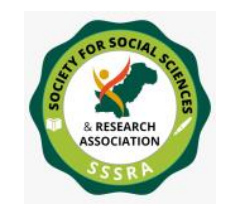

Pak. Journal of Int'L Affairs, Vol 4, Issue 4 (2021) Allama Dr Muhammad lqbal's Philosophy of ...

individual's physical existence (Aamir, 2020). The dynamics of self cater to subtle components which has a coherent relation to the society. Though, the concept of society is not a separate entity in the spirit of Islam. According to Iqbal, society plays a vital role in Human growth and development due to which an individual becomes accountable to form a better-civilized society. Iqbal cited the relation of society and self, "Self is an internal horizon of a being and society portrays the external horizon of a being. Both the self and society are in divine connection, due to which the importance of culture in Muslim society is briefly mentioned in the spirit of Islam. One of his chores such as Rumuz-i-bekhudi quotes "An individual seeks help from society, he intrinsically feels the impulse to acquire his best version, which helps him to learn discipline under the cosmological principles on Earth." Though, individual mediates the transformation of society in the perspective of cultural development (Nauman, 2018). Iqbal also discussed the relation between an Individual and society by using the phrase: "Alone he is weak and powerless, he exhibits vital energies which are immensely scattered everywhere around him, connecting to his narrow mind. Perhaps, he never becomes dormant, his livelihood is solely connected to a society which brings him to consciousness and exploring deep insights to enhance the consistency in growth and development of the (Self)." Iqbal vividly stated the universal connection between an individual's (Self) and society as an imperative gift through which he groomed himself and acquired his divinity. Iqbal's divine perspective also states individuals are the foundational component of its society (Khanday, 2018).

Indeed, society is transformed into a more sophisticated and peaceful organization through divine relations with an individual. Iqbal explicitly defended his concepts of society which depicts itself into a broad spectrum towards individuality. It's devoid of all limits and any race, or any geographical aspects. Though, it is common everywhere which maintains the coherence effect between an individual's self and the society. Moreover, its foundational unity depends on the uniform collaboration of faiths and purposes in life. Which enables one (a person) to sight visions and achieve the pinnacle of development when it comes to the (Self) and its surrounding environment. Iqbal described an ideology which inspires both individual and society is brings towards the spirit of Islam. In which he further mentioned the ideal Muslim society could be achieved through having a firm belief in Tawhid (Iqbal, 2015). Acquiring tawhid preludes the following of the last Prophet Muhammad (P.B.U.H) and practicing his (Sunnah). Iqbal deeply emphasized the integration of the Code of Ethics, guiding principles of the society in compliance with the Shariah Law, an Islamic comprehensive code of ethics. Iqbal quoted the downfall of Muslim society due to failure in compliance with the Islamic shariah code of ethics. Iqbal's strong stance enlightens the pinnacle of unity among Muslims that emerged from a Holy Place (Kabah) located in Mecca. Which exhibits a core of the Islamic belief system and it also congregates all Muslims across the globe through the holy journey (Pilgrimage) once 


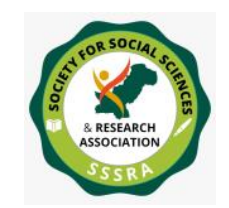

Pak. Journal of Int'L Affairs, Vol 4, Issue 4 (2021) Allama Dr Muhammad lqbal's Philosophy of ...

a year. Another perspective of divine philosophy, Iqbal also explained that A Muslim society shall be driven towards a vision and integrate their contemplation to explore the horizons in Science to acquire proficiency in it. Which he claimed a triumph in the Spirit of Islam (Razak, 2017, November 4). Perhaps, it bestows the prerequisites for preserving and promulgating the one faith Tawhid. Iqbal proposed another concept of sustaining society by honouring motherhood. Which he declared to be the true asset of society by providing uprightness of children which transcends from generation to generation (Asim, Nusrat and Khan, 2020).

\section{Iqbal's Philosophy of Moral Values}

Moral thinking is available if the inner-self incorporation principle is engaged. A decision is good if it is conscience supporting and is unethical if self-dissolving. The ethical guideline is an indispensable standard which is administered not from the thought of the conditions of a specific community or individuals yet from a plane of presence which is above spatial and worldly conditions of a specific gathering, for example a standard is good on the off chance that it isn't 'culture bound'. It rises above the social impediments of a gathering and accordingly has the proper attributes of being generalized and of being incomparable or abrogating and is trans-person (Wahid, 2018).

The social climate to which an individual has a place is comprised of customs and conventions, do's and don'ts which were existentially expert about the distant past by bonafide people. Devotion to these for the people who formulated them was basic to the importance of ethical quality. With the difference in conditions constantly which are resulting upon proficiency and expertise, moral values lose their literal meaning. They can't be, subsequently, thought of, from the view of later ages, as fundamental to profound quality. To have an ethical perspective one needs to transcend the degree of traditional qualities, to a level of presence which isn't touched with local tint got from the spirit of individuals. The ethical law is basically established by a man of good instinct (Siddiqui, 2007). The ethical representator needs to release himself from the chains of his society and approach the foundations of his soul. This sort of contact Iqbal portrays as "Travel into yourself." One can have the ethical perspective regardless of whether he stays at the degree of standard profound quality (the phase of submission to Law), a similar perspective is accessible at the degree of intelligent profound quality (the phase of self-surviving).

An individual can further reach the degree of innovative morality (the phase of Vice regime) and, according to Iqbal, a guideline to be genuinely noble must be instituted through this third and the most significant level (Asdaque, Rizvi, Tahir \& Bilal, 2011). At the point when an individual administers from the degree of imaginative ethical quality his decision isn't discretionary just like the case with some experientials however is efficiently 


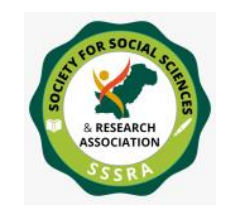

Pak. Journal of Int'L Affairs, Vol 4, Issue 4 (2021) Allama Dr Muhammad lqbal's Philosophy of ...

grounded and transcends the individual and the surroundings in most cases. To sum things up, this is an assertion of Iqbal's inception of ethical quality. He has stressed on both material and formal context as fundamental to the importance of morality (Saeed, 2015).

Iqbal portrays the ethical perspective in individualistic, material, and societal terms. A guideline or standard for Iqbal is ethical just if it is openly picked and isn't acknowledged on command. Truth be told traditional qualities are dismissed by Iqbal. Impersonation, uncritical acknowledgment of standards or qualities prompts deterioration of the ego which would thus nullify the material condition or substance component of ethical quality (Bahroni, 2011).

Iqbal builds a differentiation between the effective self and the appreciative self. The prior is simply the practical persona of everyday life, however the later is that we have in snapshots of most profound contemplation, when the proficient intellect is held in cessation. It is the spiritual focal point of involvement. You have opportunity in the most significant level when you ascend to the degree of the grateful self. Free decision is genuinely decision practiced by the obligated self. In such state a person is directly in exposure with the foundations of his existence (Parray, 2011). His perception of survival and ethics goes past the restrictions of reality. Consequently, for Iqbal a direction or standard is just when it is picked without constraint in the light of accessible information, for example isn't taken on order. The individuals who stay at the degree of traditions drop to a sub-human stage. Iqbal cites Rumi's popular lines in two of his books regarding a Shaykh who, in wide light, was wandering about with a lantern close by looking for a genuine man (Bahroni, 2011).

Presently if a standard is ethical just if it is uninhibitedly picked and is likewise held preeminent by the person, on what premise would it be able to be considered as transperson? It might be obligatory on the person who finds it or generates it. It is submerged in solid subjectivity. We should not mention about existentialists that standards and qualities are not legitimate in themselves. Your standards are legal for you as it were. You remove my liberty when you provide for your standard's societal currency (Bahroni, 2015). On what premise do you guarantee trans-individual legitimacy for your judgement? At a certain point you denounce uncritical acknowledgment of values and standards and think about your ethical principles as trans-person. Iqbal builds up the trans-person character of ethical law based on his ontological bearings. The standard of grateful self is equivalent for all. Ethical law in this plane is widespread. The obliged self gets back to you that "we are waves and ascend from the base of Being." It is this association, with the origin of all values and qualities that ensures trans-individual sustainability to standards emotionally found (Haque, 1984). 


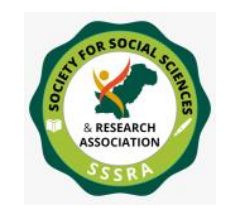

Pak. Journal of Int'L Affairs, Vol 4, Issue 4 (2021) Allama Dr Muhammad lqbal's Philosophy of ...

Nothing has been mentioned so far related to the substance or material of the ethical theory. Just conventional attributes of an ethical standard have been specified. These qualities are a rule is noble if selected bluntly in accordance with the thorough grasp on realities, is held incomparable, is universalizable and trans-person. Iqbal accepts that the ethical law has a substance viewpoint too. For Iqbal the objective of noble action is consolidation of self or character (Amir, 2009). Iqbal considers human character as a demonstration. "Hence my character isn't a thing, it is a demonstration. My experience is a progression of deeds, commonly alluding to each other and carried all together by the solidarity of a mandate purpose." Further, he cites, in the English prologue to "The Secrets of the Self', "The intention of character offers us a norm of significant worth, it resolves the issue of righteous and wicked. That which braces character is acceptable, that which debilitates it is deficient. Workmanship, religion and morals must be decided from the angle of character (Omar, 2004).

The social worry of the ethical law is similarly significant. Self can't create in separation. It needs a social climate and can't survive when deprived from it. He states (Bang-I Dara, p. 210): An individual survives by prudence of his bonds with Millat, A wave can only exist in a waterway, Outside the stream it isn't anything.

This evolution of the self is thoroughly presented by the two notions of 'Ishq and Faqr, the positive as well as negative features of La ilaha Wallah. 'Ishq represents love and supported dedication to the supreme and Faqr "demonstrates that demeaner of intellect which empowers a man to endeavour, evading all pleasures and awards with the exception of the fulfillment of commendable closures." This mentality readies the person to battle against all powers of wickedness, to save humankind from bondage. In any case, the genuine advancement of society relies upon mard-i hur (cf. Pas Chey Bāyad Kard). Narcissistic people alone uncover the profundity of life. They unveil new principles, considering that we start to notice that our current circumstance isn't entirely sacred and needs revision (Razak, 2011).

Iqbal imagines three phases in the typical advancement of the soul i.e., phases in the self-reconciliation of the individual. They are:

(i) Submission to Law. Here the individual is needed to adjust to the effective estimations of the gathering. The ethical law is a power that demonstrates from outside. This stage is trailed by:

(ii) restraint or self-surviving. This poise or self-defeating is a typical component to all originations of profound quality in the antiquated and the advanced world. "Explicit contrasts between specific moralities might be expected," states Walter A. Kaufmann, "to dissimilar originations of the focus and discipline, yet additionally of the way of self- 


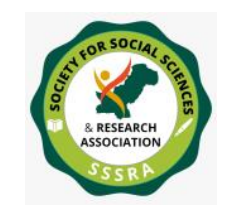

Pak. Journal of Int'L Affairs, Vol 4, Issue 4 (2021) Allama Dr Muhammad lqbal's Philosophy of ...

surviving. Hence the traditional ideal was that intentions should rule the tendencies, while Kant demanded that tendency must be controlled to a level that it may not be a co-intention of deeds." This self-discipline for Iqbal is simply how well productive self controls the supportive self.

(iii) The third phase is conceivable if productive self controls and commands the supportive self.

The indispensable experience of the grateful self is the core while aims and climax, qualities and 'standards' are its evolving appearances (Farrar, 2010).

Prior to continuing further one explanation about Iqbal's origination of ethical quality is needed. This relates to the way that individual examination is considered by Iqbal as basic to ethics. It might be contended that conscience focused morality is just illuminated personal interest. To consider social worry as important to morality might be worthy however to bind ethical quality to personal concern may misshape morality to the point of being unrecognizable. Such contentions will add up to a total misconception of Iqbal's vision with respect to the innate solidarity of people and furthermore the work of his mardI hur or mard-I momin. Iqbal's rider of fate is to quieten the commotion of countries, needs to bring fraternity and again initiate long periods of harmony to the world (Farrar, 2010).

Regarding the harmony of humankind, he cites: We neither are Afghans nor Turks nor children of Tartary. We are brought into the world in a nursery, are from the same branch. The differentiation of fragrance and colour is illegal for us as we are the infants of the same springtime. In this way material concern basic to ethical quality for Iqbal is personal and social and the demand of limited pride doesn't hold great. However, regardless of whether we yield that, for Iqbal, material worry innate for profound quality is social, the state isn't secure. The supporters of Kant may state that ethical law is just formal and has no substance. Hence content credential isn't basic to morality (Telwani, 2019).It can be encouraged that we don't indeed use the term moral just to those decisions which please the societal concerns. Some also relate it to those decisions that appeal to the desire of God. Once more, the intuitionists may reject that all ethical obligations have social recommendations. That is why social concern isn't indeed taken as important state of ethical quality. Nor would it be able to be viewed as an adequate condition for the undeniable explanation that without the state of universalization there can scarcely be any profound quality. What's more, finally if an individual were to ask: for what good reason would it be advisable for me to be socially directed? There exists no answer. Morality must convey its own consent. It should be characterized such that an individual can't reasonably ask however for what good reason? Iqbal's origination of profound quality doesn't satisfy this condition (Dar, 2013). 


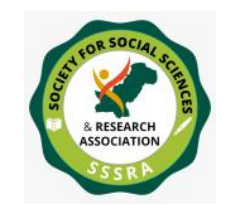

Pak. Journal of Int'L Affairs, Vol 4, Issue 4 (2021) Allama Dr Muhammad lqbal's Philosophy of ...

\section{Iqbal's thought and Challenges for Contemporary Muslim world}

What is current today seems outdated tomorrow. Innovation is a best illustration of this. A PC glances from various perspectives out of date before an advanced mobile phone, although whether we can contrast esteems and innovation is another issue. Iqbal's views were customary, yet he was a genuine pioneer of his period. His contemplations and perspectives mirrored his vision for an innovator Muslim youth and his fantasies for a public inside the domains of Islam. Iqbal's perspective on Islam depended on his profound comprehension of Quran, which upheld re-evaluating on conventional qualities, with a logical methodology. The progress from a serene, conventional society to an advanced society must be harmonious. Also, the old qualities which had the advantage of serving the public were guzzled in the re-established esteem framework. The conventional pre-Islamic ancestral society with blood fights was mixed in the invigorated moral framework, bringing about social attachment (Shah, Nahvi, \& Shafi, 2013). The exchange was to a great extent pleasant, and it influenced Iqbal profoundly, the combination of the conventional and present day. The social union achieved in Arabian deserts had a worldwide effect. To comprehend the effect, it was evaluated with a logical methodology from Imam Ghazali over to Iqbal. Iqbal was not at all apart from characteristic marvel and world occasions. The issues of life and this world consistently struck his psyche and ultimately turned out as philosophical realities.

He expressed this in his talks, which expected diverse artistic work structures articles, poems, and eloquence. Essentially talented, Iqbal took a shot at his verse to make it engage. His rhetorical craft extremely influenced crowds. Iqbal was witness to western world and with time started to severely dislike the leniency in it that downplayed communal and familial qualities. His analysis of western culture was anyway positive. He valued the logical methodology and work culture of western community (Raja, 2008). Nonetheless, the negative patterns he highlighted were a result of human encounters of centuries. The extraordinary materialism which directs man to give significance to issue more than required is indication of human destruction. The material world sees human as a tool which thus has prompted non-materialistic hardship. Iqbal's dissent against western culture depended on its materialistic perspective on life. Iqbal understood that innovation has transformed man into an item which revolves around his own body. A rigid distinction of the soul from the body has created gap between body, soul as well as religion. Religion that was once mean of divine salvation has separated and deteriorated individuals (Ahmed, 2013). To emerge from this profound degeneration he composes, anyway he doesn't deplore scholarly advancement of Europe rather he desires to follow their achievement in different fields including science and innovation. Recognition and criticism of components of western society and its social premises keep on coincide in his judgment. As indicated 


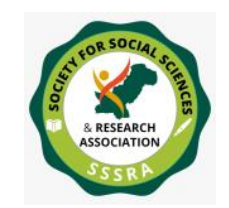

Pak. Journal of Int'L Affairs, Vol 4, Issue 4 (2021) Allama Dr Muhammad lqbal's Philosophy of ...

by Iqbal present day world stands demanding reestablishment of moral framework and faith in higher illustration can morally set up today's man for the equivalent. As a Muslim he emphasized on following Islam as a lifestyle which is modern world's necessity. Iqbal sees Islam as a living power liberating the perspective of man from its topographical restriction. He states that "Islam is solely fate and won't endure a fate" (Majeed, 2020). He condemned patriotism, communism, and thought about them as weapons of European colonialism. Iqbal was resistant to all sort of European suppression which incorporates east, of laborers via land proprietors, of employees by investors. For this he highlighted that religion must perform an imperative and compelling part. Iqbal thinks of Islam as a binding power and depicts his perspectives on community as, "It isn't the solidarity of nation or language or the recognition of financial profits that establishes the basic standards of our ethnicity (Umar, 2012).

It is on the grounds that we have faith in a specific perspective on the universe and take interest in the very noteworthy custom that we are individuals of the community established by the founder of Islam (PBUH). The current situation of our community in all aspects is enough to comprehend Iqbal's vision and connection to current occasions we are living in. To keep pace with current thoughts and time, our way of life ought to stay Muslim in character else we will lose our personality and independence (Ozturk, 2018). In Iqbal's view the youthful Muslims ought to seek to turn into exemplary Muslim and show God's ascribes however much as could be expected. Iqbal has set objectives in his various sonnets for Muslim renovators to possess new direction of the belief and opportunity to represent religion in view of propelling experience. His scorn of conventional mullahs was notable. He portrays genuine profound guide as more impressive and predominant than a ruler. A genuine religious guide is an origin of solidarity while it isn't the same with a ruler. A profound guide possesses loftier spot in the Creator's assembly than a ruler. These alleged Mullahs and Maulvis neglected to continue the prophetic aim of spreading legitimate information on Islam and filling in as good examples of devotion and learning. He cites it as: The saint, motivated by God, who neglects to incite to actions of power and prime, is only like a leaf of hemp which is careless with regards to profit or loss (Hillier \& Koshul eds, 2015). These sections obviously uncover Iqbal's conviction that profound and moral coaching of the majority should be in the possession of divine individuals.

The current society needs such men. Women's freedom is likewise a modern issue about which he wrote clearly and widely. The liberation trend endured severely due to the misinterpreted ideas of freedom. In his article "Position of Women in East" he states, "What affects me more than anything is that respect towards the women, for what Europeans were once renowned for, is getting atavistic. In underground, gents don't give up their seats to women, or do it rarely. In their way out from the vehicle they have no idea 


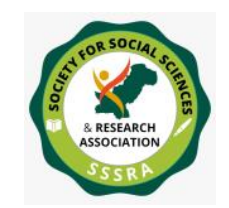

Pak. Journal of Int'L Affairs, Vol 4, Issue 4 (2021) Allama Dr Muhammad lqbal's Philosophy of ...

to let the women out first. "I would prefer not to accuse them but the ladies themselves have achieved it. They needed liberation equivalent rights as secured by the males. The transition that has occurred was inescapable. "Iqbal thought about women as holy and in this way enormity of ladies upset him a lot without a doubt. He detested the Turkish conviction that ladies haVE a substandard function in a family. For Iqbal, ladies were an image of more noteworthy regard and that is why their safety should be ensured. Iqbal's message to secure ladies shows up so appropriately today when we spot ladies to be a survivor of male strength, sexual abuse just as instructive hardship (Sevea, 2012).

\section{Findings and Recommendations}

Presently Muslim community is confronting various types of problems like frail economy, ignorance, radicalism, sectarianism, philosophical uncertainty and so forth which should be labelled, and their solutions be investigated. In these situations, the content of Iqbal turns out to be substantially more applicable to fix these issues as in the time of Iqbal the Muslim community also encountered practically comparative circumstances. Iqbal's work is being studied worldwide particularly in the Muslim community. The initiative of recently made Pakistan had an incredible duty to plan constitution of a new Islamic country based on two Nation Theory to get the strict radicals far from state undertaking because the moderate way of thinking would not acknowledge any such nation where traditional adaptation of Islam wouldn't get key significance.

When this nation came into existence, we had occasions to advance however due to the tragic death of Quaid we diverged from our path. In today's time, individuals need to teach their youngsters up to the degree with whatever they have yet there are restricted opportunities and language obstruction is a huge hurdle in their path.

We must use our mind and contribute for advancement of the nation. Iqbal asked to make our own world while utilizing the imagination. Wrong citations using his name via web-based media and negative promulgation against him can be managed by engendering his genuine message. We must encourage our youngsters about our writing and legacy embracing Iqbal's verses, letters, and addresses. Genuine motivational poems of Iqbal need to be instructed in our foundations rather than few conventional sonnets.

In Pakistan individuals don't cast a ballot to radicals and it is a major effect of Iqbal's ideology. Nusrat Fateh Ali Khan was an artistry of this society and its Iqbal's philosophy that youngsters of traditional families are singing Sufi verses even with the advent of latest music. This demonstrates the capability of our youngsters and the impact 


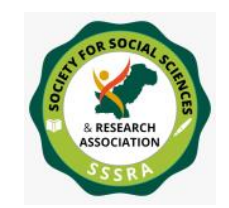

Pak. Journal of Int'L Affairs, Vol 4, Issue 4 (2021) Allama Dr Muhammad lqbal's Philosophy of ...

of Iqbal's content. Allama Iqbal is remarkable today like he was during his life. We must follow his content in managing the issues of Muslims.

Distinction between history and narration have caused negativity and to radicalism. We need to eradicate the false concepts that are available to our nation. We need to investigate ourselves that what sort of commitment we have in current world regarding information. We can advance on the planet simply by gaining ground in science and innovation. Today tragically we are users of present-day innovations and not the creators of new advancements or developments. We should look for information as opposed to restricting ourselves just to data.

Today although it is a period of data innovation yet there are numerous inquiries and doubt in the brain of individuals particularly youngsters with respect to religion and philosophy. Indeed, even on Iqbal's admiration we are partitioned on the grounds that we don't have time and occasions to debate and appropriately explore it. Public talks and conversations are required. Iqbal tended to the adolescent in his message as youngsters are the fate of a country. For our public rehabilitation Iqbal requested to liberate our minds from a wide range of terror, boundaries, and subjection and thus, our youth can become heads of the country. Iqbal needed revolt in one's personality since Allah's messenger (PBUH) first introduced his living and demonstrated the personality prior to teaching Islam.

Pakistan movement was the first Ijtihadi development to frame a isolated sovereign country for the Muslims living in India. For this development, Iqbal upheld Quaid-e-Azam Muhammad Ali Jinnah who was a modest and taught character. In this way Quaid's character offers what was the idea of Pakistan as a main priority of Iqbal. Iqbal discussed philosophical states particularly when one country has a way of life, history and heritage of its own. In this viewpoint, Iqbal portrayed two nation theory. Iqbal was in opposition to slavery yet tragically we are immersed in it till date. Profound democracy portrayed by Iqbal set apart, we are also distant from democracy of the west. In Muslim states, even western autonomy can conduct much progress. We need to follow up on lessons of Iqbal else we can't confront the advanced world with progress. As per Iqbal's vision, parliament ought to pursue obligation of Ijtihad because specialists of various fields and overall population would be occupied while the preeminent power is owned by Allah-the supreme. Iqbal talked about the connection between Allah and His creations and depicted the function of man in this dynamic globe which is going through change with each second. 


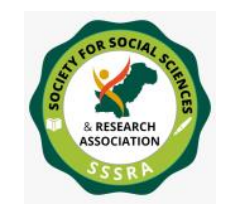

Pak. Journal of Int'L Affairs, Vol 4, Issue 4 (2021) Allama Dr Muhammad lqbal's Philosophy of ...

\section{Conclusion}

Allama Iqbal, writer of the East, was an incredible scholar for Muslim community as well as for mankind. His work is appreciated worldwide and goes past the restrictions of topography or a specific mindset. Iqbal discussed the contribution of Muslims for the evolving world. He reproduced all thoughts of that time and with the teachings of Quran, never took sides with any custom or society.

Iqbal's view of soul has been inspected since he asserted that comprehension of soul is fundamental for comprehension of the idea of literature and concept of its development. He is extremely observant that the convention of self-denial has crawled into and hued Muslim idea though it is basically conflicting with the vision of Islam. Rather than some strict and philosophical ways of thinking which deprecated the truth of soul and viewed it as a figment of brain and not having any gravity, Iqbal taught us perception of the real meaning of self. For Iqbal, self is a genuine and above all huge entity that is the core and foundation of the complete association of human existence.

Considering his concept of self-declaration or self-acknowledgement, Iqbal built an endeavour to decipher the truth of life regarding human work and decisions. By lecturing complete appreciation of one's self in the genuine universe of powers, Iqbal attempted to display a unique nature of the Muslims' opinion and lead. Moreover, he stated that the advancement of a dynamic personality is impractical besides in contact with a cultural climate. Hence, he has specified an equivalent significance to an individual and mankind in the advancement of Muslim values. Iqbal was very conscious of the standards of a society's customs for the improvement of the person. The progression of social existence relies upon the role of its individuals conducting both an authentic acknowledgement and a basic evaluation of its social qualities and conventions. They should have the limit with respect to dynamic agreement, absorption, and recreation of the current culture. Also, Iqbal talked about three roots of information referenced in the Quran: intellectual exploit, history and nature in his conversation about the soul of Muslim society. To disclose the genuine soul of Muslim society, as indicated by Iqbal, Muslim masterminds must not mention the theoretical idea of Greek beliefs which appreciated judgement and disregarded realities. The soul of Muslim culture depends on the solid and limited. He strongly accepted that the introduction of strategy for perception and trial in Islam isn't because of a trade off with Greek idea yet to a delayed scholarly conflict with it. Iqbal named this a scholarly revolution against Greek way of thinking. 
Pak. Journal of Int'L Affairs, Vol 4, Issue 4 (2021) Allama Dr Muhammad lqbal's Philosophy of ...

\section{References}

Aamir, R. (2020). Praxix Of Pereniality: Emerson's “Self Reliance” And Iqbal's Concept Of 'Khudi'. Iqbal Review 61(2): 21

Abbas, S. R. (2017). (intern) Iqbals Concept of Khudi and its Implication in Education (Doctoral dissertation, University of Management and Technology).

Ahmed, S. (2013). Reform and modernity in Islam: The philosophical, cultural and political discourses among Muslim reformers. Bloomsbury Publishing.

Al-Azhari, Z., \& Ghuman, M. N. (2019). Human Moral Values \& Allama Iqbal. Islamic Studies Research Journal Abhāth, 4(14), 101-121.

Ali, B. Z. (2011). Iqbal's Notion of an'Islamic Modernity'. Global Political Thought https://doi.org/10.7916/D8PG20TK

Ali, M. A. (2017). Iqbal's Inferences from the Qur'an: Objectives of Education for Developing the Individual Self. Journal of Education and Educational Development, 4(2). 321-345.

Amin, P. M. (2012). Allama Iqbal on the Reality of Man: A Psycho-Philosophical Perspective. International Journal of Literary Studies, 2(2), 109-114.

Amir, Z. M. (2009). Special Feature: Islamic Moderate Trends in South Asia. In Muhammad Iqbal's Concept of Islam. Kyoto Bulletin of Islamic Area Studies, 2(2), $22-35$.

Asdaque, M. M., A. A. Rizvi, A. G. Tahir And M. Bilal (2011). Allama Iqbal's Concept Of Meer-E-Caravan And Its Application To Leadership Styles Of Heads Of Secondary Schools In Pakistan. International Journal of Academic Research 3(3).

Ashraf, S. E. (2003). A Critical Exposition of Iqbal's Philosophy. Adam Publishers.

Asim, S., Nusrat, A and Khan, S (2020). A Comparative Study of Walt Whitman and Dr. Allama Muhammad Iqbal on "SELF"." SJESR 3(3): 176-183.

Bahroni, I. (2011). Individuality In the Educational Philosophy of Allama Muhammad Iqbal. At-Ta'dib 6(1). 
Pak. Journal of Int'L Affairs, Vol 4, Issue 4 (2021) Allama Dr Muhammad lqbal's Philosophy of ...

Bahroni, I. (2011). Philosophy of Character Education: A Study on the Conception of AM Iqbal. At-Ta'dib 6(2).

Bahroni, I. (2015). Personality Education According To Allama Muhammad Iqbal. AtTa'dib 10(2).

Britannica, T. Editors of Encyclopaedia (2020, May 2). Sir Muhammad Iqbal summary. Encyclopedia Britannica.

https://www.britannica.com/summary/Muhammad-Iqbal

Dar, M. A. (2013). Social philosophy of Allama Muhammad Iqbal: views on Ummah and Islamic society. Islam and Muslim Society, 6(1), 76-82.

Farrar, A. M. (2010). Conceptions of Religion: Exploring the Converging and Diverging Religious Philosophies of Muhammad Iqbal and Friedrich Nietzsche.

Haque, I. (1984). Concepts and Dimensions of Morality. Islamic Studies 23(3): 265-288.

Hillier, H. C., \& Koshul, B. B. (Eds.). (2015). Muhammad Iqbal: Essays on the Reconstruction of Modern Muslim Thought. Edinburgh University Press. http://www.jstor.org/stable/10.3366/j.ctt16r0jgm

Iftikhar, H., Anwar, M. J., \& Tehreem, R. (2018). The Mediating Role of Moral SelfConcept among Physician: Compassion Regulations: A Measurement of Medical Student Development. Asian Journal of Multidisciplinary Studies, 6, 2.

Iqbal, M. (2013). The Reconstruction of Religious Thought in Islam. Stanford University Press.

Iqbal, Z. M. (2015). Iqbal: Poet, Philosopher, and His Place In World Literature. Xlibris Corporation.

Khaja, M. A. (2018). Nationalism in the writings of Iqbal and Said Nursi: A Comparative study of their perspectives. A Social Science Journal, 11, 49-62.

Khan, T. I., Akbar, A., Jam, F. A., \& Saeed, M. M. (2016). A Time-Lagged study of the relationship between big five Personality and Ethical Ideology. Ethics \& Behavior, 26(6), 488-506. 
Pak. Journal of Int'L Affairs, Vol 4, Issue 4 (2021) Allama Dr Muhammad lqbal's Philosophy of ...

Khanday, K. A. (2018). IBN Khaldun and Allama Iqbal as Educationists. International Journal of Advanced Multidisciplinary Scientific Research (IJAMSR) 1(9), 87-93. https://www.ijamsr.com/issues/6_Volume\%201_Issue\%209/20190209_080235_11.p df

Majeed, J. (2020).Muhammad Iqbal: Islam, Aesthetics and Postcolonialism. Taylor \& Francis.

Muzaffar, C. (2002). Iqbal and the Challenge of Reform within the Muslim World. Intellectual Discourse, 10(2).

Nauman, S. (2018). Iqbal-education and cultivation of self: a way forward for Muslims of the subcontinent. Educational Philosophy and Theory 50(4): 326-337.

Omar, I. A. (2004). Khiżr-i Rāh: The Pre-Eminent Guide to Action in Muhammad Iqbal's Thought. Islamic Studies 43(1): 39-50.

Ozturk, S. (2018). Becoming a Genuine Muslim: Kierkegaard and Muhammad Iqbal. Routledge.

Parray, T. A. (2011). Allama Iqbal on Islam-Democracy Discourse: An Analysis of His Views on Compatibility and Incompatibility. Islam and Muslim Societies 4(2): 1-14.

Popp, S. (2019). Muhammad Iqbal-Reconstructing Islam along Occidental Lines of Thought. Interdisciplinary Journal for Religion and Transformation in Contemporary Society, 5(1), 201-229.

Puspitasari, R. (2019). The Concept Of Muhammad Iqbal Education Education (Godhead Perspective). AIUA Journal of Islamic Education, 1(2), 147-170.

Raja, M. A. (2008). Muhammad Iqbal: Islam, the West, and the Quest for a Modern Muslim Identity. The International Journal of the Asian Philosophical Association, 1(1), 33-45.

Razak, M. A. A. (2011). Iqbal's ideas for the restoration of Muslim dynamism. Journal of Islam in Asia. 8: 377-402. 
Pak. Journal of Int'L Affairs, Vol 4, Issue 4 (2021) Allama Dr Muhammad lqbal's Philosophy of ...

Razak, M. A. A. (2017, November 4). Iqbal: The Man and His Mission in Life. Convention on Muslim Thinkers: Revitalisation of Muslim Spirit, IKBAR Festival 2017, Arena Citra Room ICC, International Islamic University Malaysia.

Saeed, A. (2015). Allama Iqbal's concept of nation is helpful for national solidarity in Pakistan. International Journal of Physical and Social Sciences 5(6): 89-102.

Saeed, A. L. (2013). Allama Muhammad Iqbal's concept of the Ego/Khudi and the concept of unity of being. Mysticism in East and West: The Concept of the Unity of Being, 248-276.

Sevea, I. S. (2012). The Political Philosophy of Muhammad Iqbal: Islam and Nationalism in Late Colonial India. Cambridge University Press.

Shah, A. S. S., Nahvi, B. A. G., \& Shafi, A. (2013). Allama Iqbal and Contemporary Society:(A Sociological Perspective) (Doctoral dissertation). Iqbal Institute of Culture \& Philosophy University of Kashmir, Srinagar

Siddiqui, M. A. (2007). Allama Iqbal: A Critic Of Capitalism \& Globalization. IBT Journal of Business Studies (JBS) 4(1): 4-4.

Tatlah, I. A. (2011). A Review of Educational values of the Modern Muslim Thinker: Dr. Allama Muhammad Iqbal (RA). Allama Muhammad Iqbal (RA)(May 16, 2011).

Telwani, A. A. (2019). Contribution of Allama Iqbal to Muslim Educational Thought. International Journal of Advanced Multidisciplinary Scientific Research (IJAMSR) ISSN: 2581-4281, 2 (1), January, 2019,\# Art, 1116, 33-46.

Umar, M. S. (2012). Iqbal and Modern Era (pp. 187-188). Lahore: Iqbal Academy Pakistan.

Wahid, A. (2018). A Comparative Study On Educational Thoughts Of Allama Iqbal And Imam Ghazali In The Opinion Of Educationist. Pakistan Journal of Educational Research 1(1). 